\title{
Dimensi konsep diri korban cyber sexual harassment di Kota Pekanbaru
}

\author{
Welly Wirman', Genny Gustina Sari², Fitri Hardianti ${ }^{3}$, Tegar Pangestu Roberto ${ }^{4}$ \\ ${ }_{1,2,4}$ Universitas Riau, Riau, Indonesia \\ ${ }^{3}$ Universitas Islam Riau, Riau, Indonesia
}

\begin{abstract}
ABSTRAK
Kasus pelecehan seksual cyber kerap terjadi di Kota Pekanbaru, hal ini dapat dilihat dari pemberitaannya di beberapa media massa. Tidak adanya data akurat di P2TP2A Kota Pekanbaru tentang pelecehan seksual dunia maya menunjukkan bahwa kurangnya pengetahuan dan kepedulian publik tentang cyberbullying terhadap remaja. Penelitian ini bertujuan untuk menentukan dimensi internal dan dimensi eksternal konsep diri serta pengalaman komunikasi dari remaja korban cyber sexual harrassment. Penelitian ini menggunakan metode kualitatif dengan pendekatan fenomenologi, teknik pengumpulan data terdiri dari wawancara mendalam, observasi, dan dokumentasi. Teknik pengumpulan informan dalam penelitian ini menggunakan teknik Snowball, dan jumlah informan dalam penelitian ini berjumlah enam orang. Teknik analisis data yang digunakan adalah Miles dan Huberman. Sementara teknik pemeriksaan keabsahan data menggunakan perpanjangan keikutsertaan dan triangulasi. Hasil dalam penelitian ini menunjukkan bahwa dimensi internal konsep diri pada remaja terdiri dari identitas diri negatif. Perilaku mereka pesimistis, tidak mampu mengendalikan emosi, dan remaja cenderung mendapatkan penilaian negatif dalam bentuk label seksual dari teman-teman mereka seperti "menggairahkan", "pelacur" dan sebagainya. Kemudian dimensi eksternal yang terdiri dari fisik di mana remaja merasa bentuk fisik atau wajah yang dimiliki dapat memprovokasi pelecehan, merasa kurang baik dalam hal moral-etika karena mereka tidak mengikuti ajaran yang diajarkan oleh agama, selain itu jika dilihat dari pribadi adanya kecemasan, berpikir negatif, dan skeptis tentang pujian. Pengalaman komunikasi yang menyenangkan diperoleh dalam bentuk motivasi, perhatian, dan konseling, pengalaman komunikasi yang tidak menyenangkan seperti korban disalahkan, ejekan, dimarahi oleh orang tua, dan dianggap melebih-lebihkan.
\end{abstract}

Kata-kata Kunci: Konsep diri; remaja; cyber sexual harassment; pengalaman komunikasi; Pekanbaru

\section{Dimensions of self consept cyber sexual harassment's victims in Pekanbaru city}

\section{ABSTRACT}

The cases of Cyber sexual harassment often occur in Pekanbaru where it can be seen in several mass media. The absence of accurate data in P2TP2A Pekanbaru about sexual harassment in cyberspace shows the lack of public knowledge and concern about cyberbullying towards adolescents. This study aims to determine the internal dimensions and external dimensions of self-concept and communication experiences of victims of cyber sexual harassment. This study uses qualitative method with phenomenological approaches, data collection techniques used were in-depth interviews, observation, and documentation. The informants were gathered by Snowball technique with the total of informants are six people. The data analysis technique used are from Miles and Huberman. Meanwhile, the technique of data validity check are extension of participation and triangulation. The results indicate that the internal dimensions of self-concept in adolescents is negative self-identity. Their behaviors are pessimistic, having uncontrolled emotions, and get negative judgments from their friends such as "voluptuous", "prostitutes" and so on. Then the external dimension consisting of physical, where adolescents feel their physical appearance can provoke harassment, feel poorly on moralethics because they are not religious. Moreover, from personal being, they have anxiety, negative thinking, and skeptical about compliment. A pleasant communication experiences were obtained in the form of motivation, attention, and counseling, unpleasant communication experiences such as victim blaming, being ridicule, scolded by parents, and being considered exaggerating.

Keywords: Self conceptual; adolescents; cyber sexual harassment; communication experience; Pekanbaru

Korespondensi: Dr. Welly Wirman, S.IP., M.Si. Universitas Riau. Kampus Bina Widya Km 12,5 Simpang Baru Pekanbaru 28293 - Indonesia.Email:welly.wirman@lecturer.unri.ac.id

Submitted: May 2020, Accepted: March 2021, Published: June 2021

ISSN: 2303-2006 (print), ISSN: 2477-5606 (online). Website: http://jurnal.unpad.ac.id/jkk

Terakreditasi Kemenristekdikti RI SK No. 48a/E/KPT/2017 


\section{PENDAHULUAN}

Cybercrime adalah kejahatan dimana tindakan kriminal hanya bisa dilakukan dengan menggunakan teknologi cyber dan terjadi di dunia cyber (Fajri, 2008). Cybercrime dalam arti luas meliputi setiap perilaku ilegal yang dilakukan dengan maksud atau berhubungan dengan sistem komputer dan jaringan, termasuk kejahatan pemilikan, penawaran atau distribusi dari komputer sistem atau jaringan (Lisanawati, 2014). Pendapat lainnya tentang cybercrime yakni sebagai perbuatan melawan hukum yang dilakukan dengan memakai jaringan komputer sebagai sarana / alat atau komputer sebagai objek, baik untuk memperoleh keuntungan ataupun tidak, dengan merugikan pihak lain (Arifah, 2011). Di Indonesia UndangUndang Informasi dan Transaksi Elektronik (UU ITE) Nomor 11 Tahun 2008 sudah disahkan oleh Dewan Perwakilan Rakyat (DPR). Berdasarkan Undang-Undang ITE, terdapat berbagai macam bentuk kejahatan di dunia maya (cybercrime) seperti pornografi, perjudian, penghinaan, pencemaran nama baik, pemerasan, pengancaman, carding, politic hacker, teror, abuse, pembajakan, penyadapan, dan sebagainya. Salah satu bentuk cybercrime dari segi pornografi adalah cyber sexual harassment. Pelecehan seksual di dunia maya (cyber sexual harassment) dapat secara sederhana didefinisikan sebagai "pelecehan seksual yang terjadi terutama melalui internet". Menurut Dowdell dalam American Journal of Nursing, cara termudah hari ini bagi pelaku untuk bertemu dan melibatkan anak atau remaja untuk tujuan sexual harassment, pornografi, atau prostitusi adalah melalui internet (Rosyidah \& Nurdin, 2018).

Cybersex bukan merupakan topik baru, namun keberadaannya semakin dikenal karena praktiknya juga ikut berkembang. Goldberg mengatakan bahwa banyaknya orang yang menggunakan Internet untuk cybersex telah meningkat sepuluh tahun terakhir ini (Juditha, 2020). Hal ini berdampak serius pada dorongan seksual pengguna, karena seringkali tidak mampu menahan dorongan seksual karena sajian seks di internet tersebut. Sexual harassment memiliki implikasi sosial sebagai bentuk dari diskriminasi gender dan agresi seksual. Terutama memengaruhi kesehatan mental pada perempuan (Reed, Wong, \& Raj,
2019). Organisasi Kesehatan Dunia menegaskan bahwa sexual harassment merupakan salah satu bentuk kekerasan seksual yang menjadi masalah global (Rusyidi, Bintari, \& wibowo, 2019). Ada beberapa dampak negatif dari praktik cybersex, seperti prostitusi, kejahatan cyber termasuk pelecehan anak dan pornografi. Tahun 2014, UNICEF melaporkan bahwa satu dari sepuluh anak perempuan mengalami sexual harassment. Data ini mungkin belum bisa diyakini sepenuhnya, karena pelecehan seksual membuat orang yang dilecehkan tidak nyaman tanpa menimpa sakit fisik yang berat sehingga masih banyak sexual harassment tidak dilaporkan. Oleh karena itu, perilaku pelecehan tidak terdata dengan baik, baik itu di lembaga-lembaga hukum maupun lembaga sosial masyarakat. Namun demikian, apabila ini terus dibiarkan akan berakibat pada kehidupan masyarakat yang tidak aman dan nyaman (Rahmah, Iriyanti, Maghfiroh, \& Agustina, 2017).

Adapun contoh pemberitaan terkait pelecehan seksual di dunia maya (cyber sexual harassment) yang ada di media seperti diberitakan di riaugreen.com, menyebutkan bahwa terdapat remaja berusia 18 tahun yang melapor ke Diskominfo Riau mengenai gambargambar porno yang diterimanya melalui orang asing di media sosialnya. Selain itu ada pula penelitian terdahulu oleh Ahmad Fatikhul Abdullah, STKIP PGRI Sidoarjo yang berjudul studi fenomenologi pelecehan seksual pada wanita melalui sosial media, dengan tujuan untuk mengetahui bentuk-bentuk pelecehan seksual yang terjadi pada media sosial dan respons pengguna media sosial terhadap pelecehan seksual tersebut (Abdullah, 2008).

Penelitian lainnya juga dilakukan oleh Sloane Burke W, dkk. Tentang "Exploring Cyber Harrassment among Women Who Use Social Media". Total keseluruhan responden terdapat 293 perempuan dewasa dengan usia 18 tahun ke atas yang menyelesaikan survei dengan baik. Menyebutkan bahwa responden yang ketika ditanya tentang pengalaman mereka dengan berbagai bentuk pelecehan dunia maya dalam 12 bulan terakhir (tidak termasuk spam), $19,9 \%(\mathrm{n}=57)$ telah berulang kali menerima pesan cabul yang tidak diminta di Internet dari seseorang yang tidak mereka kenal. Lebih dari $10 \%(11,5 \%, \mathrm{n}=33)$ telah menerima pesan pornografi, dan hampir seperlima $(19,2 \%, \mathrm{n}=$ 
55) berulang kali menerima ajakan seksual di Internet dari seseorang yang tidak mereka kenal (Jasmine, 2021).

Kemajuan teknologi yang semakin pesat layaknya pisau bermata dua tidak hanya membawa dampak positif namun diikuti juga dengan serangkaian dampak negatif (Habibah \& Tianingrum, 2020). Kemudahan dan kecanggihan teknologi informasi saat ini, menciptakan peluang-peluang baru dalam tindakan kriminal. Pelaku melakukan pelecehan melalui berbagai jenis media sosial dan teknologi komunikasi, terlebih lagi korban yang ditemui merupakan remaja yang masih dalam masa transisi menuju pendewasaan. Di Indonesia kasus kekerasan seksual setiap tahun mengalami peningkatan, korbannya bukan hanya dari kalangan dewasa saja sekarang sudah merambah ke remaja, anak-anak bahkan balita (Noviana, 2015).

Menurut Lidya Mawarni, M.H dari Lembaga Bantuan Hukum Pekanbaru dalam Pelatihan Pencegahan KBGO di Pekanbaru, bahwasanya kekerasan yang terjadi di dunia nyata atau online tidak dapat didiamkan begitu saja, sebagai masyarakat memiliki hak dan kewajiban untuk mencegah kekerasan seksual tersebut. Salah satu langkahnya adalah dengan speak-up atau mengungkapkan kejadian yang menimpa sekitar kita baik teman, saudara atau diri sendiri, mencari perlindungan hukum juga merupakan hal yang benar untuk dilakukan (Dreeva, 2019).

Salah satu penyebab dari belum berakhirnya kekerasan seksual terhadap perempuan di Indonesia adalah dianutnya budaya patriarki dalam masyarakat Indonesia. Patriarki sendiri dapat diartikan sebagai sistem pengelompokkan masyarakat sosial yang mementingkan garis keturunan laki-laki. Dalam kehidupan masyarakat, paham patriarki berkembang menjadi sebuah cara untuk mendiskriminasi perempuan dengan menganggap perempuan sebagai pihak yang lebih inferior (Rahayu \& Agustin, 2018).

Penulis melakukan observasi dan wawancara sederhana kepada informan kunci, NI yang menjadi salah satu korban cyber sexual harassment. Remaja yang aktif pada komunitas dan forum antipatriarki ini aktif bermedia sosial dan membahas isu-isu gender nasional dan pelecehan, suatu ketika ia membagikan pengalamannya di media sosial mengenai pelecehan didunia maya . NI mengatakan : "Pelaku video call berkali-kali dan nelfon selalu tengah malam. Aku angkat ternyata video dia lagi liatin itu nya. Terus dia nelfon pakai nomor lain, pas di angkat dia mendesah-desah. Terus setelah aku block, dia pakai nomor lain lagi whatsapp ke aku foto itu dia, tapi gak aku tanggapin, terus dia chat aku, katanya aku jual mahal dan ngancam mau ambil keperawanan aku. Semenjak itu aku gak berani keluar-keluar rumah jadi takut manatau pelaku tau aku lagi dimana". (Wawancara NI, pada 12 Januari 2019).

Rata-ratakorban yang mengalami pelecehan di dunia maya cenderung memiliki konsep diri negatif, hal ini terlihat dari dirinya yang tidak percaya diri, malu terhadap diri sendiri, tertutup, dan pemurung. Terlintas pemikiran dalam benak penulis bahwa pengalaman tersebut dapat mempengaruhi kehidupan dan cara pandang mereka. Seorang remaja yang tengah mematangkan konsep dirinya mengalami pengalaman negatif tersebut yang mempengaruhi cara pandang terhadap dirinya dan lingkungan sekitar, dimana hal tersebut dapat mempengaruhi pola komunikasinya secara interpersonal dengan lingkungan sekitar. Penulis juga melakukan wawancara dengan seorang psikolog pada 18 April 2019 di Persona Quality yang merupakan Kantor Pusat Layanan Psikologi Pekanbaru. Menurut Ibu Irene Hutajulu S.Psi selaku psikolog, mengatakan "kasus cyber sexual harassment ini lebih mengerikan dibandingkan pelecehan di dunia nyata karena pelaku tidak bisa dilawan secara langsung karena membutuhkan keberanian yang kuat dari pihak korban untuk membalas tindakannya. Korban tidak bisa lari apabila ia masih terhubung dengan dunia maya." (Wawancara dilakukan pada 18 April 2019)

Kasus cyber sexual harassment sudah marak terjadi di Kota Pekanbaru, dengan dimuatnya dibeberapa media massa, pada tahun 2017 Provinsi Riau menjadi provinsi yang menduduki peringkat ke-2 di Indonesia yang memiliki kasus kekerasan seksual terhadap anak terbanyak, kekerasan seksual tersebut terus meningkat setiap tahunnya hingga 2019. Menurut Kepala Bidang Perlindungan Anak dan Perempuan, dari Dinas Pemberdayaan Perempuan dan Perlindungan Anak Kota 
Pekanbaru, Sarkawi Datuak Mongguang Kayo "Jumlahnya mengalami peningkatan cukup besar dibandingkan kasus yang sama 2017 lalu yang hanya 74 kasus dan 2016 sebanyak 63 kasus". Menurut beliau, pemicu terjadinya kejahatan seksual terhadap anak-anak atau remaja secara umum akibat degradasi moral pada sejumlah oknum warga, pengaruh tayangan pornografi di ponsel, dan kurang perhatian dari pihak keluarga (Nashrullah, 2019).

Tidak adanya data di Pusat Pelayanan Terpadu Pemberdayaan Perempuan dan Anak (P2TP2A) Kota Pekanbaru mengenai remaja yang mendapatkan cyber sexual harassment menandakan bahwa kurangnya pengetahuan dan kepedulian masyarakat mengenai pelecehan didunia maya terhadap para remaja. Hal ini menjelaskan bahwa Cyber Sexual harassment sudah menjadi rahasia umum di dalam masyarakat, hingga saat ini belum ada data valid yang mengumpulkan jumlah laporan cyber sexual harassment di Pekanbaru. Kurangnya kesadaran masyarakat mengenai bahayanya cyber sexual harassment bagi perkembangan konsep diri dan perilaku komunikasi seseorang, membuat fenomena cyber sexual harassment ini tidak diatur secara serius. Pandangan masyarakat yang mengganggap pelecehan visual, verbal, maupun teks di dunia maya sebagai masalah sepele membuat korbannya merasa tabu untuk membuka suara, berkonsultasi, atau melaporkan hal tersebut

Pada akhir 2018 dan 2019, kasus ini sudah cukup merajalela di Kota Pekanbaru sehingga banyak dimuat dalam beberapa media online. Seperti yang dimuat oleh tribunpekanbaru.com dimana korban yang bernama Wirzha mengaku Facebook-nya terpampang foto mesum, Wirzha kemudian mengadukan hal ini ke polisi. Kasus berikutnya dimuat oleh riaugreen.com dimana korban pelecehan seksual berumur 18 tahun mengadu ke Diskominfo Riau. Selain itu juga ada pemberitaan di merdeka.com dimana korban mengaku profil di FB nya berubah menjadi gambar porno, korban lantas lapor kepada polisi, ada pula kasus warga tenayan raya tega posting video mesum dengan pacarnya di facebook yang dimuat di riauterkini.com dan lain-lain.

Berdasarkan jurnal Internasional Project deShame (Childnet, 2017), pelecehan seksual secara online telah dikategorikan ke dalam empat jenis utama, namun hanya dua kategori yang dijadikan fokus dalam penelitian ini yaitu Eksploitasi, paksaan, dan ancaman (seseorang menerima ancaman seksual, dipaksa untuk berpartisipasi dalam perilaku seksual online atau blackmail yang berisikan konten seksual), dan Perilaku seksual yang tidak diinginkan (seseorang menerima konten dan komentar seksual yang tidak dinginkan), karena penulis menemukan jenis pelecehan ini yang banyak ditampilkan di berbagai media massa dan di Kota Pekanbaru. Pelecehan jenis satu dan empat memiliki dampak besar ke lingkungan sosial, bersifat personal, dan berbentuk foto atau video yang ditambah dengan teks. Korban mengalami gangguan psikis seperti perasaan malu yang kuat, terancam, merasa terhina, takut dirinya buruk dimata orang lain, dan sebagainya, sehingga korban menjadi menarik diri, bermasalah dengan lingkungan sosial, pindah sekolah, melapor kepihak berwajib, hingga membunuh.

Salah satu bentuk cybercrime dari segi pornografi adalah cyber sexual harassment. Pelecehan seksual di dunia maya (cyber sexual harassment) dapat secara sederhana didefinisikan sebagai "pelecehan seksual yang terjadi terutama melalui internet". Pelecehan seksual secara online dapat terjadi melalui media yang berbeda seperti ruang obrolan, situs jejaring sosial, kotak masuk (inbox), e-mail, iklan, tautan otomatis atau spam. Penulis memfokuskan pada kasus korban yang mengalami cyber sexual harassment melalui ruang obrolan, situs jejaring sosial, dan kotak masuk (inbox) karena menurut survei wearesocial.com jumlah pengguna sosial media di Indonesia mencapai 56\% dari jumlah penduduk Indonesia, dan penggunaan sosial media serta aplikasi messenger merupakan aktivitas yang paling sering dilakukan.

Fenomena cyber sexual harassment banyak melanda para remaja, dilihat dari pemberitaan dan pengguna aktif internet di Indonesia yang 49,52\% di dominasi usia 1934 tahun. Remaja adalah masa perkembangan transisi antara masa anak-anak dan masa dewasa yang mencakup perubahan biologis, kognitif, dan sosial-emosional (Santrock, 2007). Berdasarkan penelitian yang dilakukan Ahmed E. Arafa, Rasha, Nahed \& Safaa dampak yang ditimbulkan dari cyber sexual harassment meninggalkan banyak gangguan psikologis, mulai dari tekanan emosional, kesedihan, kesepian, marah, hingga gejala 
depresi dan menghalangi aktivitas sehari-hari (Arafa, 2018). Selain itu juga kasus kekerasan seksual mampu memberikan traumatik korban yang lama (Indainanto, 2020).

Pada penelitian ini guna mengungkap konsep diri dan pengalaman komunikasi dari remaja korban cyber sexual harassment maka penulis menggunakan teori Interaksi simbolik. Interaksi simbolik didasarkan pada ide-ide tentang bagaimana individu melakukan interaksi dengan individu lainnya. Interaksi simbolik merupakan aktivitas yang menjadi ciri khas manusia yakni komunikasi dan pertukaran simbol-simbol yang diberi makna. Dalam teori ini melihat bahwa perilaku manusia dilihat sebagai proses yang memungkinkan manusia membentuk dan mengatur perilaku mereka dengan mempertimbangkan feedback dari orang lain. Perilaku seseorang dipengaruhi oleh simbol yang diberikan oleh orang lain, demikian pula perilaku orang tersebut. Melalui pemberian isyarat berupa simbol, maka kita dapat mengutarakan perasaan, pikiran, maksud, dan sebaliknya dengan cara membaca simbol yang ditampilkan oleh orang lain.

Tiga konsep utama dalam teori interaksi simbolik oleh Mead, yaitu mind, self, dan society dapat dijabarkan sebagai berikut : Pertama, Pikiran (Mind), pikiran menghasilkan suatu bahasa isyarat yang disebut sebagai simbol. Simbol-simbol yang memiliki arti bisa berbentuk gerak gerik atau gesture dan juga dapat berupa bahasa. Pikiran adalah mekanisme penunjuk diri (self-indication) untuk menunjukkan makna kepada diri sendiri dan kepada orang lain dan berkembang dalam proses sosial komunikasi. Pikiran merupakan hal yang membedakan manusia dengan makhluk hidup lainnya karena mind melalui proses berfikir. Kedua, Diri Pribadi (Self), Self atau diri adalah kemampuan untuk menerima diri sendiri sebagai sebuah objek dari perspektif yang berasal dari orang lain, atau masyarakat. Diri muncul dan berkembang melalui aktivitas interaksi sosial dengan orang lain. Proses melihat diri sendiri melalui sudut pandang orang lain merupakan cara yang efektif bagi individu untuk masuk ke dalam tatanan sosial karena dengan begitu individu akan mampu untuk menilai kekurangan ataupun kelebihan yang ada pada dirinya. Konsep ini merujuk pada seperangkat persepsi yang relatif stabil yang dipercaya individu mengenai dirinya.
Terdapat dua kemungkinan yaitu, individuindividu mengembangkan konsep diri melalui interaksi dengan orang lain. Kedua, konsep diri memberikan motif yang penting bagi perilaku seseorang. Ketiga, Masyarakat (Society), masyarakat dalam konteks pembahasan George Herbert Mead dalam teori Interaksi Simbolik ini adalah masyarakat dalam ruang lingkup mikro, yaitu organisasi sosial tempat akal budi (mind) serta diri (self) muncul. Bagi Mead dalam pembahasan ini, masyarakat itu sebagai pola-pola interaksi dan institusi sosial yang adalah hanya seperangkat respons yang biasa terjadi atas berlangsungnya pola-pola interaksi tersebut, karena Mead berpendapat bahwa masyarakat ada sebelum individu dan proses mental atau proses berpikir muncul dalam masyarakat.

Teori Interaksi simbolik mengasumsikan bahwa makna diciptakan melalui interaksi dan dimodifikasi melalui interpretasi. Teori ini juga mengasumsikan bahwa manusia berinteraksi dengan manusia lainnya tergantung pada makna yang diberikan. Komunikasi yang efektif tidak akan terjadi tanpa adanya makna yang dibagikan. Kita akan mudah berkomunikasi dengan orang yang memiliki kesamaan bahasa dengan kita dibandingkan dengan mereka yang tidak memiliki kesamaan bahasa dengan kita. Begitu pula dalam memahami makna simbolik, kita akan mudah memahami suatu makna yang hendak disampaikan apabila mengetahui maksud dari simbol yang diberikan.

Konsep diri terbentuk melalui proses pembelajaran dirimulai dari kecil hingga dewasa. George Herbert Mead menjelaskan konsep diri sebagai pandangan, penilaian, dan perasaan individu mengenai dirinya yang timbul sebagai hasil dari suatu interaksi sosial (Handaningtias \& Agustina, 2017). Lingkungan, pengalaman, dan pola asuh orang tua memberikan pengaruh yang signifikan dalam membentuk konsep diri seseorang. Hal-hal tersebut membantu seseorang untuk dapat mengenali siapa dirinya. Konsep diri mempunyai sifat yang dinamis atau dapat berubah. Ada aspek-aspek yang bisa bertahan dalam jangka waktu tertentu dan ada yang mudah berubah sesuai dengan situasi yang dihadapi. Seperti penelitian Roshi Khoirunnisa, Universitas Negeri Yogyakarta. Penelitian yang berjudul konsep diri remaja korban bullying (studi pada siswa korban bullying di SMA Muhammadiyah 7 Yogyakarta), memperlihatkan 
hasil bahwa konsep diri terbentuk dari dimensi internal (diri pribadi) dan dimensi eksternal (interaksi dan lingkungan sosial). Apabila korban mengalami pengalaman negatif dari luar secara terus menerus akan membentuk konsep diri yang negatif pula.

Menurut Fitts konsep diri seseorang dipengaruhi oleh beberapa faktor yaitu pengalaman, kompetensi, aktualisasi diri, pola asuh orang tua, kegagalan, depresi, dan kritik internal (Agustiani, 2009). Pengalaman yang diperoleh dalam kehidupan dapat mempengaruhi konsep diri seseorang karena konsep diri adalah hasil dari sebuah interaksi individu dengan lingkungannya, maka pengalaman interpersonal merupakan faktor yang paling penting bagi perkembangan konsep diri seseorang. Pengalaman interpersonal yang menimbulkan perasaan positif maupun negatif dan berharga. Kemudian kompetensi yang dimaksud adalah pengakuan atau dihargai oleh individu lain. Pengakuan atau harga diri yang diberikan individu lain terhadap dirinya dapat mempengaruhi perkembangan konsep dirinya. Seperti dalam penelitian Hikmah Widyana Intan, Universitas Gunadarma. Penelitian yang berjudul konsep diri remaja korban perkosaan ini memperlihatkan bahwa pengalaman negatif seperti pemerkosaan yang terjadi saat remaja membentuk konsep diri negatif terhadap diri korban.

Cyber sexual harassment merupakan suatu bentuk pengalaman negatif. Pengalaman negatif maupun positif merupakan salah satu faktor yang mempengaruhi pembentukan konsep diri seseorang. Masa remaja merupakan tahap pematangan konsep diri individu. Sehingga apabila pengalaman negatif terjadi dimasa remaja, hal tersebut dapat mempengaruhi terbentuknya konsep diri. Menurut Fitts konsep diri seseorang memiliki aspek-aspek yang dibagi menjadi beberapa dimensi yaitu dimensi internal dan eksternal (Agustiani, 2009). Dimensi internal memiliki tiga indikator yaitu identitas (identity self), diri perilaku (behavioral self) dan diri penerimaan (judging self). Dalam dimensi eksternal terdapat lima indikator yaitu fisik (physical self), diri moral etik, diri keluarga , diri pribadi , dan diri sosial. Tujuan penelitian ini dilakukan adalah untuk mengetahui bagaimana aspek-aspek tersebut terbentuk setelah seseorang mengalami pengalaman dilecehkan melalui dunia maya. Adapun tujuan dari penelitian ini adalah untuk menentukan dimensi internal dan dimensi eksternal konsep diri serta pengalaman komunikasi dari remaja korban cyber sexual harrassment.

\section{METODE PENELITIAN}

Metode penelitian yang akan digunakan adalah kualitatif dengan pendekatan fenomenologi. Rivai (Creswell, 2016) juga menyebutkan bahwa metode kualitatif digunakan secara induktif, dengan asumsi yang didasarkan pada konstruk realitas sosial, variabel yang sulit diukur, kompleks dan saling terkait dan data yang dikumpulkan berisi sudut pandang yang mendalam dari informan.

Selanjutnya menentukan subjek penelitian, yang artinya orang pada latar penelitian yang dimanfaatkan untuk memberikan informasi tentang situasi kondisi latar penelitian (Moleong, 2010). Pengambilan subjek menggunakan teknik snowball sampling. Penulis menggunakan informan kunci (key informan) untuk membangun akses kepada informan-informan lainnya, berawal dari satu informan kemudian membesar dan meluas. Informan penelitian adalah subjek atau pihak yang mengetahui atau memberikan informasi maupun kelengkapan mengenai objek penelitian. Saat ini yang menjadi subjek penelitian ini adalah : 4 perempuan ((NI (Informan kunci), MU, NC, dan MA)), 2 laki-laki (DA dan NA).

Adapun sumber data dalam penelitian ada dua, yakni data primer dan data sekunder. Data primer dapat berbentuk opini subjek individu atau kelompok, dan hasil observasi terhadap karakteristik benda (fisik), kejadian, kegiatan dan hasil suatu pengujian tertentu Ruslan (Intan, 2015). Data primer yang penulis dapatkan untuk meneliti konsep diri korban cyber sexual harassment di Kota Pekanbaru akan berasal dari pengamatan interaksi para korban cyber sexual harassment di kota Pekanbaru terhadap lingkungan dan dirinya sendiri. Kemudian, data primer akan didapatkan dari hasil wawancara terhadap subjek-subjek penelitian.

Sedangkan data sekunder adalah data yang didapat tidak langsung dari sumbernya dimana hal ini diambil dari arsip yang dapat memberikan data tambahan yang mendukung analisis dan interpretasi data (Sugiyono, 2016). Data sekunder dalam penelitian ini diperoleh langsung dari korban cyber sexual harassment 
Tabel 1 Simbol dalam Cyber Sexual Harassment

\begin{tabular}{|c|c|c|c|}
\hline No. & Simbol / Singkatan & Arti & Penjelasan \\
\hline 1 & & Terong & $\begin{array}{l}\text { Penggunaan emoji ini sering menjadi simbol } \\
\text { yang berkaitan dengan alat kelamin pria }\end{array}$ \\
\hline 2 & & Buah Persik & $\begin{array}{l}\text { Emoji ini sering disalah gunakan sebagai } \\
\text { penggambaran bokong wanita yang besar }\end{array}$ \\
\hline 3 & & Buah Pisang & $\begin{array}{l}\text { Penggunaannya sama dengan emoji terong, } \\
\text { namun pisang digambarkan sebagai alat kelamin } \\
\text { pria yang belum disunat }\end{array}$ \\
\hline 4 & & Lidah & $\begin{array}{l}\text { Emoji ini bermakna atau menggambarkan } \\
\text { kegiatan oral seks (kegiatan seksual } \\
\text { menggunakan mulut) }\end{array}$ \\
\hline 5 & & $\begin{array}{l}\text { Bulir Air/ } \\
\text { Keringat }\end{array}$ & Menyimbolkan cairan sperma laki-laki \\
\hline 6 & & Menyeringai & $\begin{array}{l}\text { Dalam konteks seksual, emoji ini bermaksud } \\
\text { untuk menggoda seseorang }\end{array}$ \\
\hline 7 & & $\begin{array}{l}\text { Mengedipkan } \\
\text { Mata }\end{array}$ & $\begin{array}{l}\text { Ekspresi mengedipkan sebelah mata memiliki arti } \\
\text { mencoba menggoda seseorang }\end{array}$ \\
\hline 8 & 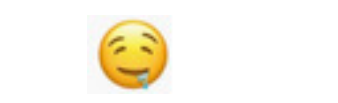 & Air liur & $\begin{array}{l}\text { Emoji ini menggambarkan ekspresi tergiur dan } \\
\text { terangsang karena melihat tubuh seseorang }\end{array}$ \\
\hline 9 & PS & Phonesex & $\begin{array}{l}\text { Aktivitas berbicara melalui telefon dengan orang } \\
\text { lain mengenai kegiatan seksual dengan maksud } \\
\text { membuat mereka menjadi terangsang }\end{array}$ \\
\hline 10 & VCS & Video Call Sex & $\begin{array}{l}\text { Melakukan panggilan video siaran langsung } \\
\text { diaplikasi tertentu, kemudian menunjukkan } \\
\text { bagian tubuh sensitif seperti alat kelamin atau } \\
\text { lekuk tubuh }\end{array}$ \\
\hline 11 & $\mathrm{BO}$ & Booking Out & $\begin{array}{l}\text { Mengajak seseorang keluar dan menginap } \\
\text { disuatu tempat untuk berhubungan seksual, biasa } \\
\text { digunakan oleh jasa prostitusi online }\end{array}$ \\
\hline 12 & Send Nudes & Foto Vulgar & $\begin{array}{l}\text { Meminta foto vulgar atau telanjang melalui pesan } \\
\text { singkat maupun aplikasi chatting }\end{array}$ \\
\hline
\end{tabular}

Sumber: Hasil Penelitian, 2019

berupa dokumentasi dan bukti data lain yang menurut penulis penting untuk dimasukkan.

Teknik pengumpulan data yang dilakukan adalah wawancara mendalam, observasi, dan dokumentasi. Pada teknik wawancara, penulis melakukan wawancara tatap muka dan mengajukan berbagai pertanyaan yang berhubungan dengan konsep diri korban. Kemudian, secara tidak langsung penulis akan melihat komunikasi non verbal dari informan seperti gerakan tangan, ekspresi wajah, gerak tubuh, dan sebagainya. Selain itu, penulis juga akan melakukan wawancara menggunakan media telekomunikasi seperti aplikasi pesan di smartphone (Whatssapp atau Line), melalui telepon, dan video conference untuk mengatasi informan yang tidak mau melakukan wawancara tatap muka karena berbagai kendala. Penulis akan mewawancarai orang terdekat informan seperti keluarga, teman, tetangga, atau sahabat informan.

Selanjutnya observasi, adapun teknik observasi yang digunakan adalah teknik observasi partisipasi pasif. Menurut Susan 
Tabel 2 Pemahaman Informan terhadap Makna Simbolik Cyber Sexual Harassment

\begin{tabular}{|c|c|c|c|c|}
\hline No. & Nama & $\begin{array}{c}\text { Pemahaman Simbol Seksual } \\
\text { Sebelum Kejadian }\end{array}$ & Sesudah Kejadian & $\begin{array}{l}\mathrm{S} u \mathrm{~m} \text { b e } \mathrm{r} \\
\text { Pemahaman }\end{array}$ \\
\hline 1. & MU & $\begin{array}{l}\text { Belum mengerti, hanya } \\
\text { menganggap hal tersebut } \\
\text { sebagai iklan spam yang } \\
\text { ada di sosial media }\end{array}$ & $\begin{array}{l}\text { Menjadi lebih paham setelah } \\
\text { menanggapi pesan yang } \\
\text { dikirim pelaku, memahami } \\
\text { maksud pelaku dan } \\
\text { memahami gelagat orang } \\
\text { yang memiliki niat tidak baik }\end{array}$ & $\begin{array}{l}\text { Mencari tahu } \\
\text { sendiri }\end{array}$ \\
\hline 2. & DA & $\begin{array}{l}\text { Belum mengerti, hanya } \\
\text { mengetahui apabila } \\
\text { seseorang mengirim gambar } \\
\text { tidak senonoh artinya } \\
\text { merendahkan diri kita }\end{array}$ & $\begin{array}{l}\text { Lebih memahami bahwa } \\
\text { gambar atau pesan yang } \\
\text { dikirim sama saja seperti } \\
\text { melihat langsung didunia } \\
\text { nyata, namun perbedaannya } \\
\text { pelakunya tidak diketahui }\end{array}$ & $\begin{array}{l}\text { Kakak dan teman } \\
\text { terdekat }\end{array}$ \\
\hline 3. & NA & $\begin{array}{l}\text { Memahami ada yang } \\
\text { salah dari pesan yang } \\
\text { diterimanya, namun tidak } \\
\text { tahu cara menghadapinya }\end{array}$ & $\begin{array}{l}\text { Jauh lebih tahu, ada yang } \\
\text { berbentuk verbal, gambar, } \\
\text { chat, link menjebak, } \\
\text { video, video call, dan } \\
\text { mengetahui emoticon yang } \\
\text { memiliki makna ganda, } \\
\text { serta mengetahui cara } \\
\text { menghadapinya }\end{array}$ & Teman dekat \\
\hline 4. & NI & $\begin{array}{l}\text { Tidak terpikir bahwa } \\
\text { seseorang bisa dilecehkan } \\
\text { melalui sosial media }\end{array}$ & $\begin{array}{l}\text { Mengetahui istilah seksual } \\
\text { seperti BO, send nude, } \\
\text { PS, dan mengetahui cara } \\
\text { menanggulanginya }\end{array}$ & $\begin{array}{l}\text { Mencari tahu } \\
\text { sendiri di internet } \\
\text { dan bertanya } \\
\text { kepada teman }\end{array}$ \\
\hline 5. & $\mathrm{NC}$ & $\begin{array}{l}\text { Sudah mengetahui sekilas } \\
\text { mengenai cyber sexual } \\
\text { harassment dari teman yang } \\
\text { mengalami }\end{array}$ & $\begin{array}{l}\text { Jadi tahu istilah-istilah, } \\
\text { emoticon, dan apa saja } \\
\text { hal yang memiliki makna } \\
\text { "menggoda" yang dilakukan } \\
\text { lawan jenis seperti pose } \\
\text { mengeluarkan lidah }\end{array}$ & Teman dekat \\
\hline 6. & MA & $\begin{array}{l}\text { Belum tahu, ia hanya } \\
\text { mengetahui bahwa tidak } \\
\text { seharusnya melihat gambar } \\
\text { seperti itu, ia merasa } \\
\text { berdosa dan takut ketahuan } \\
\text { orang tua }\end{array}$ & $\begin{array}{l}\text { Lebih memahami kenapa } \\
\text { pada saat itu ia merasa } \\
\text { bathinya sebagai perempuan } \\
\text { memberontak karena } \\
\text { mendapat gambar yang } \\
\text { melanggar norma dan etika } \\
\text { yang dianutnya. MA bisa } \\
\text { mengetahui gelagat orang } \\
\text { yang ingin memberikan pesan } \\
\text { menjurus kearah seksual }\end{array}$ & $\begin{array}{l}\text { Teman yang } \\
\text { pernah } \\
\text { mengalami } \\
\text { kejadian yang } \\
\text { sama. }\end{array}$ \\
\hline
\end{tabular}


Stainback (Sugiyono, 2016) observasi partisipasi pasif, penulis datang ke tempat kegiatan orang yang diamati, tetapi tidak ikut terlibat dalam kegiatan tersebut. Alasan penulis menggunakan teknik ini karena penulis ingin mengetahui kegiatan sehari-hari subjek yang diamati berkaitan dengan konsep diri subjek, tapi tidak terlibat langsung dalam kegiatan subjek korban cyber sexual harassment. Observasi dilakukan di tempat dimana subjek melakukan aktivitasnya baik di tempat belajar, lingkungan rumah maupun di tempat kerjanya, serta di akun sosial medianya (aktivitas dunia maya). Selain itu observasi juga dapat dilakukan di rumah subjek yaitu saat subjek menjawab pertanyaan yang diajukan penulis.

Terakhir, dokumentasi. Meleong mengemukakan dua bentuk dokumen yang dapat dijadikan bahan dalam studi dokumentasi, yaitu Dokumen Harian (pribadi) dan Dokumen Resmi (Moleong, 2010). Penulis akan menggunakan Dokumentasi pribadi yang umum digunakan yaitu catatan harian atau diary (jika ada), surat pribadi (e-mail, social media, chat box, dsb).

Teknik analisis data menggunakan interaktif Miles dan Huberman. Untuk mencapai keabsahan data dalam penelitian ini, penulis menggunakan perpanjangan keikutsertaan dan triangulasi.

\section{HASIL DAN PEMBAHASAN}

Pada fenomena remaja korban cyber sexual harassment, anak yang belum mengetahui simbol-simbol dan tanda pelecehan seksual akan mengalami kesulitan pemahaman makna sehingga anak tidak dapat menghindari pelecehan, tidak tahu cara menanggulanginya, dan shock karena tidak memiliki bekal pengetahuan terhadap makna dari simbol-simbol tersebut. Salah satu cara anak mendapatkan pemahaman tersebut yaitu dari edukasi seks yang diberikan orang tuanya, namun beberapa orang tua menganggap edukasi seksual adalah tabu bagi anak. Alasannya, pengetahuan tersebut akan mengalir seiring berjalannya usia mereka. Bahkan, beberapa orang tua masih tampak bingung untuk memberikan edukasi kepada anaknya.

Cyber Sexual Harrassment ini juga terdapat simbol atau singkatan yang digunakan pelaku saat melakukan cyber sexual harassment (Pada tabel 1). Sementara itu bentuk (mind) pikiran korban yang muncul sebelum dan sesudah mengalami cyber sexual harassment ketika simbol-simbol signifikan digunakan dalam proses komunikasi dan dipengaruhi oleh pemahaman society (masyarakat) (Pada tabel 2).

Selain teori Interaksi simbolik, penulis juga menggunakan konsep dari konsep diri untuk menjawab tujuan penelitian, Fitts (Agustiani, 2009) mengatakan bahwa konsep diri berpengaruh kuat terhadap tingkah laku seseorang. Dengan mengetahui konsep diri seseorang, kita akan lebih mudah meramalkan dan memahami tingkah laku orang tersebut. Pada umumnya tingkah laku individu berkaitan dengan gagasan-gagasan mengenai dirinya sendiri. Jika seseorang mempersepsikan dirinya sebagai orang yang superior dibandingkan dengan orang lain, walaupun dalam hal ini belum tentu benar, biasanya tingkah laku yang ia tampilkan berhubungan dengan kekurangan yang dia persepsi secara subyektif tersebut (Cangara, 2011).

Selanjutnya penulis juga menggunakan konsep dari pengalaman komunikasi, Pengalaman merupakan sesuatu yang dialami. Hal ini sesuai dengan pernyataan bahwa, "all objects of knowledge must conform to experience" (Wirman, 2012) pengetahuan melandasi kesadaran yang membentuk pemaknaan. Kesadaran yang membentuk pemaknaan inilah yang mendorong individu untuk melakukan tindakan atau perilaku tertentu, dengan merujuk pada, "behavior is an experience of consciousness that bestows meaning through spontaneous activity" (Wirman, 2012). Setiap peristiwa yang dialami akan menjadi sebuah pengalaman bagi individu. Pengalaman yang diperoleh mengandung suatu informasi atau pesan tertentu. Informasi ini akan diolah menjadi pengetahuan. Dengan demikian berbagai peristiwa yang dialami dapat menambah pengetahuan individu.

Suatu peristiwa yang mengandung unsur komunikasi akan menjadi pengalaman komunikasi tersendiri bagi individu dan pengalaman komunikasi yang dianggap penting akan menjadi pengalaman yang paling diingat dan memiliki dampak khusus bagi individu tersebut (Wirman, 2012). Pengalaman yang dijadikan landasan bagi individu untuk melakukan tindakan adalah pengalaman yang melekat pada sesuatu, "people is retrieving a 
memory of a prior experience of phenomena" (Wirman, 2012).

Penjelasan mengenai pengalaman komunikasi yang menyenangkan dan tidak menyenangkan dapat diawali dengan pernyataan, komunikasi memiliki dimensi isi dan dimensi hubungan (Wirman, 2012). Hal ini berarti pengalaman komunikasi yang menyenangkan (positif) dapat ditinjau, antara lain melalui suatu hubungan yang menunjukkan adanya kehangatan sikap, penerimaan dan perhatian satu sama lain. Sedangkan pengalaman komunikasi yang tidak menyenangkan (negatif) berarti sebaliknya.

Berdasarkan dari deskripsi teori dan konsep yang telah dipaparkan di atas, maka penulis akan mengaitkan teori dan konsep diatas dengan konsep diri dan pengalaman komunikasi dari remaja korban cyber sexual harassment. Pertama, penulis akan membahas dimensi internal konsep diri, yang dimaksud dengan dimensi internal atau juga disebut kerangka acuan (internal frame of reference) adalah penilaian yang dilakukan individu yaitu penilaian yang dilakukan seseorang terhadap dirinya sendiri berdasarkan dunia di dalam dirinya. Dalam dimensi internal terdapat 3 bentuk yaitu a). Identitas Diri (identity self), dalam hal ini, umumnya remaja korban cyber sexual harassment memiliki konsep diri yang cenderung negatif, remaja korban cyber sexual harassment yang memiliki identitas diri yang berbeda-beda dimana mereka merasa mempunya identitas tersendiri yang menggambarkan siapa mereka sebenarnya dengan dilatar belakangi mereka adalah remaja korban cyber sexual harassment sehingga mereka merasa memiliki kepercayaan diri yang rendah, malu dengan diri sendiri, melankolis (perasaan muram), penakut, suka menyendiri, pemurung, pesimis, dan cenderung menutup diri.

Dari pertanyaan mengenai identitas diri seperti MA dan MU merasa bahwa dirinya adalah orang yang lemah, pesimis, lebih suka menyendiri, pemurung dan penakut saat berada di keramaian atau di dekat lawan jenis, berbeda dengan NI dan NC yang memiliki identitas diri yang pemarah, tidak dapat mengontrol emosi yang akan diluapkan, sangat mudah tersinggung, sensitif dalam menerima pesan dan memiliki kepercayaan diri yang rendah. Sedangkan DA dan NA yaitu korban laki-laki yang tidak terlalu mengalami perubahan sifat namun menjadikan dirinya sebagai seorang yang tidak lagi ekspresif, negative thinking, tertutup, dan pembenci.

Adapun penyebab konsep diri identitas yang cenderung negatif ini disebabkan oleh pengalaman cyber sexual harassment yang merendahkan dan menginjak harga diri anak, dan menyuguhkan mereka dengan hal-hal seksual yang dianggap berlawanan dengan norma yang dianut selama ini seperti ajakan berhubungan seksual, foto alat kelamin, video bermasturbasi dan ungkapan yang memiliki makna negatif bahkan terkadang mengancam untuk mencari korban dan melakukan pelecehan didunia nyata. b). Diri pelaku (behavioral self), diri pelaku merupakan persepsi remaja korban cyber sexual harassment tentang tingkah lakunya, yang berisi segala kesadaran mengenai apa yang dilakukan oleh dirinya. Selain itu bagian ini berkaitan erat dengan diri identitas. Diri yang kuat akan menunjukkan adanya keserasian antara diri identitas diri pelaku, sehingga seseorang tersebut dapat mengenali dan menerima, baik diri sebagai identitas maupun diri sebagai pelaku. Kaitan keduanya dapat dilihat pada diri sebagai penilai. Label label yang melekat pada remaja korban cyber sexual harassment juga mempengaruhi perilaku mereka dimana informan menunjukkan perilaku rendah diri.

Berdasarkan hasil di lapangan yang penulis lakukan dengan salah seorang remaja korban cyber sexual harassment yaitu MA yang merasa sentimental dengan dirinya karena dikekang oleh rasa malu sekaligus karena adanya ancaman dari pelaku sehingga mengarahkan dirinya menjadi remaja yang suka menangis, sombong dan menghindari komunikasi dengan lawan jenis, NC juga suka menarik diri dari orang tuanya seperti menghindari interaksi kepada mereka, memendam perasaan dan suka merendahkan dirinya. Berbeda dengan MU, setelah mendapatkan cyber sexual harassment ia merasa tahu segalanya tentang pelecehan sehingga suka memotong pembicaraan, lancang, dan berbicara kotor. Hal tersebut memperlihatkan sisi negatif perlakuan MU sama halnya dengan informan NA yang suka berkata kasar dalam mengekspresikan perasaannya, tidak dekat dengan keluarga dan emosinya mudah terpancing. NI menjadi anak yang suka menyindir, tidak mau disalahkan, mudah panik, tidak dekat dengan keluarga 
namun mandiri dalam menghadapi masalah. Sedangkan DA adalah remaja yang tidak dapat mengontrol emosi, suka menantang, dan berani mengeluarkan pendapat agar dirinya tidak lagi direndahkan oleh calon-calon pelaku dan masyarakat.

Kesimpulan yang diperoleh adalah korban suka berkata kasar atau menghardik, menghindari keramaian, kaku, suka merendahkan diri, menyendiri, mudah panik, menghindar dari keluarga, sombong, dan tertutup. c). Penerimaan diri/ penilaian diri (judging self), penilaian diri remaja korban cyber sexual harassment berfungsi sebagai pengamat, penentu standar, dan evaluator sebagai perantara mediator antara identitas dan diri pelaku remaja korban cyber sexual harassment. Mereka cenderung memberikan penilaian terhadap apa yang dipersepsikan. Oleh karena itu, label-label yang dikenalkan pada dirinya bukanlah semata-mata menggambarkan dirinya namun juga sarat dengan nilai-nilai bagi remaja korban cyber sexual harassment, sehingga penilaian ini menentukan para remaja dalam tindakan yang akan ditampilkannya, karena diri penilaian menentukan kepuasan seseorang akan dirinya atau seberapa jauh seseorang menerima dirinya. Kepuasan diri yang rendah akan menimbulkan harga diri yang rendah pula dan akan mengembangkan ketidak percayaan yang mendasar pada dirinya. Di sini korban merasa tidak senang dengan penilaian yang diberikan orang kepadanya seperti cabe, bohay, bahenol, merasa tidak dihargai, menjadi tidak percaya diri dengan citra yang dibawa, merasa harga diri rendah, hina dan dilecehkan. Kedua, dimensi eksternal konsep diri, pada dimensi eksternal remaja korban cyber sexual harassment menilai dirinya melalui hubungan dan aktifitas sosialnya, nilai-nilai yang dianutnya, serta hal-hal diluar dirinya. Dimensi eksternal merupakan suatu hal yang luas, seperti diri yang berkaitan dengan lingkungan sosial, sekolah, agama, organisasi dll, namun dimensi eksternal yang dikemukakan oleh William H. Fitts adalah dimensi eksternal yang bersifat umum bagi orang yang dibedakan atas lima bentuk yaitu : a. Diri Fisik, diri fisik menyangkut persepsi remaja korban cyber sexual harassment terhadap keadaan dirinya secara fisik, persepsi mereka mengenai kesehatan dirinya, penampilan dirinya seperti cantik, jelek, menarik dan tidak menarik serta keadaan tubuhnya seperti tinggi, pendek, langsing, gemuk. Pada dasarnya remaja korban cyber sexual harassment memiliki kesamaan dalam penampilan fisik dengan remaja biasa lainnya, seperti penampilan mereka yang tidak ada ubahnya, mengikuti trend dan penampilan layaknya seusia remaja pada umumnya. Hanya perasaan mereka yang berbeda. Sebagian korban merasa percaya diri dengan bentuk fisiknya dan merasa cyber sexual harassment tidak mempengaruhi tingkat kepercayaan diri fisiknya. Namun sebagian lagi merasa malu karena gemuk, mengeluh ketika bercermin, tidak percaya diri dengan dada dan bokong yang besar, dan tidak nyaman dengan kecantikan yang dimilikinya. b). Diri Moral-Etik, Diri moraletik merupakan persepsi remaja korban cyber sexual harassment tentang dirinya yang dilihat dari standar pertimbangan nilai-nilai, moral dan etika. Hal ini menyangkut persepsi remaja korban cyber sexual harassment mengenai hubungannya dengan Tuhan, kepuasannya terhadap kehidupan keagamaannya dan nilainilai moral yang dianutnya, yang meliputi batas baik dan buruk. Informan mendapatkan contoh moral etika yang tidak baik dari lingkungan, pelaku, dirinya sendiri dan orang tua mereka, seperti berkata kasar atau tidak menutup aurat. Sebagian besar moral etik informan berasal dari pemahaman dirinya sendiri dan keluarga seperti kurangnya dorongan beribadah dari keluarga, tidak bersyukur dengan bentuk tubuh, dan sebagainya. Sehingga korban merasa kurang puas antara hubungannya dengan tuhan, tidak mengikuti ajaran agama (terutama cara berpakaian), berbuat dosa, dan merasa tidak memiliki etika yang cukup baik di lingkungan sosial. c). Diri Personal, diri personal merupakan perasaan atau persepsi remaja korban cyber sexual Harassment tentang keadaan pribadinya. Hal ini tidak dipengaruhi oleh kondisi fisik atau hubungan dengan orang lain, tetapi dipengaruhi oleh sejauh mana karakteristik atau watak di dalam diri remaja korban cyber sexual Harassment dan diyakini sebagai pribadinya. Dalam hal ini korban memiliki karakter kritis, agresif, skeptis terhadap pujian, melihat masalah dari sisi negatif. d). Diri Keluarga, Dalam keluarga, akan menunjukkan perasaan dan harga diri remaja korban cyber sexual harassment dalam kedudukannya sebagai anggota keluarga. Bagian ini akan menunjukkan seberapa jauh remaja korban cyber sexual harassment merasa kuat terhadap dirinya sebagai anggota keluarga, 


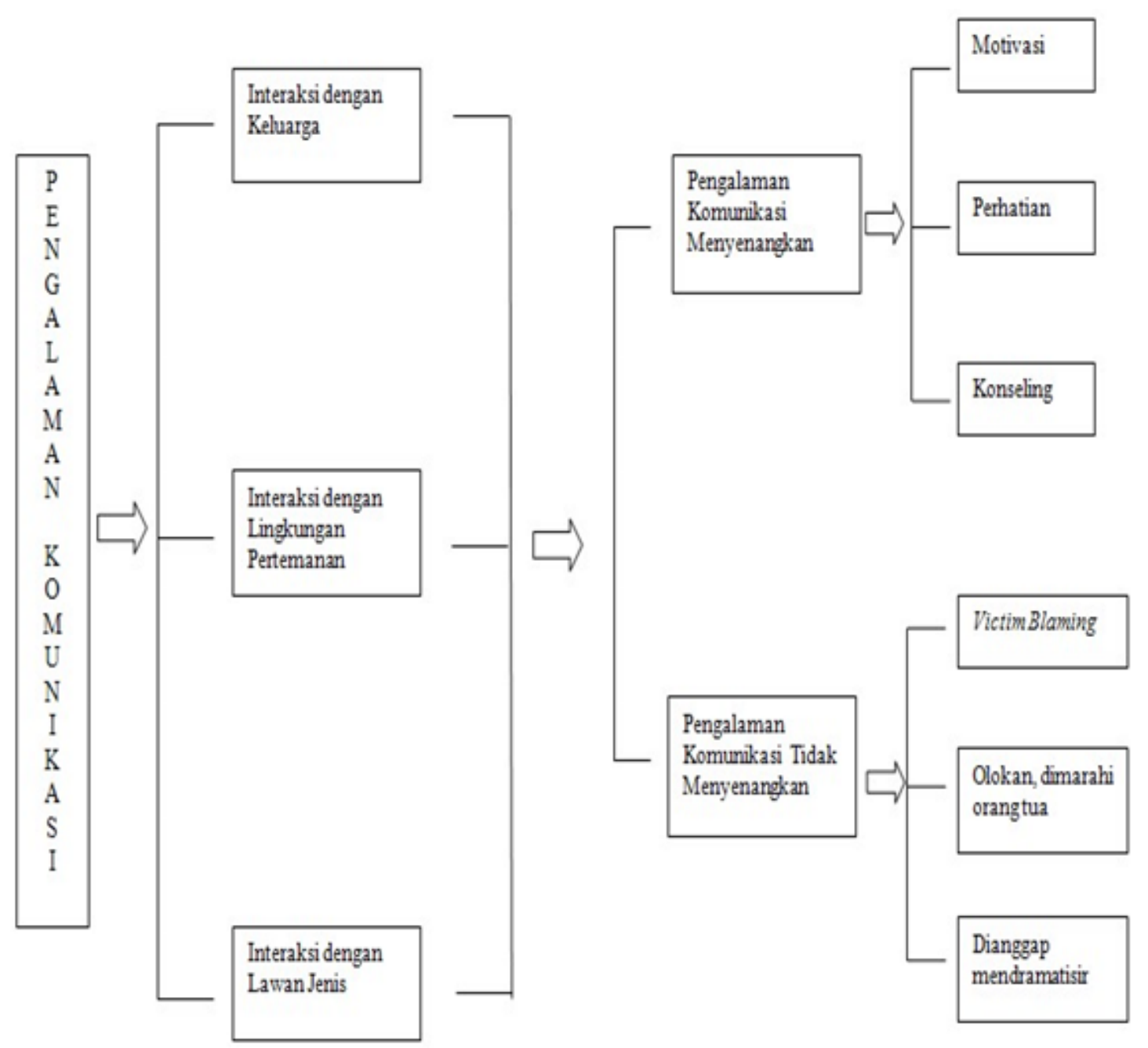

Sumber: Olahan Penulis, 2019

\section{Gambar 1 Model Pengalaman Komunikasi Remaja Korban Cyber Sexual Harassment}

serta peran maupun fungsi yang dijalankannya sebagai anggota dari suatu keluarga. Dalam hal ini korban merasa diri mereka tidak dimengerti oleh orang tua, selalu merasa tertekan, merasa tidak nyaman berada dekat dengan orang tua, dan sering melakukan komunikasi menarik diri pada kedua orang tuanya. e). Diri Sosial, Diri sosial merupakan penilaian remaja korban cyber sexual harassment terhadap interaksinya dengan orang lain maupun lingkungan di sekitarnya. Pembentukan penilaian remaja korban cyber sexual harassment terhadap bagian-bagian dirinya ini dapat dipengaruhi oleh penilaian dan interaksinya dengan orang lain. Ucapan-ucapan bernada menghina dan merendahkan dari pelaku akan direkam dalam pita memori remaja, semakin lama dan sering mereka mengalami cyber sexual harassment tersebut maka akan semakin bertambah depresi dan membuat remaja memiliki citra negatif. Dalam diri sosial, korban merasa enggan untuk menambah teman, menghindari interaksi dengan orang baru, sulit menyesuaikan diri, tidak menjadi diri sendiri ketika berada di luar, menjauhi lawan jenis, dan membentengi jalur pertemanan dan interaksi baik di dunia nyata maupun dunia maya.

Selanjutnya jika dilihat berdasarkan karakteristik konsep diri (Rakhmat, 2009) yang telah dipaparkan, terlihat bahwa gambaran diri remaja korban cyber sexual harassment memiliki gambaran citra diri yang negatif dimana mereka merasa yang telah mereka lakukan dan penilaian mereka terhadap dirinya bersifat negatif. Sementara itu ada juga remaja korban cyber sexual harassment yang akhirnya 
memiliki gambaran diri positif dimana ia merasa apa yang telah mereka lakukan dan penilaian mereka bersifat positif tanpa merugikan diri mereka, dan berguna untuk dirinya dimasa depan. Berdasarkan pengamatan dan data yang disaring maka penulis memaparkan bahwa semua informan memiliki konsep diri yang cenderung negatif dimana remaja korban cyber sexual harassment menilai negatif diri mereka dan sulit untuk mengenal diri mereka lebih baik.

Terakhir, penjelasan mengenai pengalaman komunikasi yang terbentuk setelah remaja korban cyber sexual harassment berinteraksi dengan significant others (keluarga terdekat) dan reference group (teman dan lingkungan sekitar) tercipta dua bentuk pengalaman komunikasi yaitu pengalaman komunikasi menyenangkan dan tidak menyenangkan. Pengalaman komunikasi menyenangkan terdiri dari motivasi yang didapat oleh orang tua dan teman yang peduli dengan kisah korban, mereka mendapatkan dukungan untuk bangkit kembali (segi psikis), diberikan nasihat, serta dituntun untuk melihat sisi positif dari kejadian pelecehan tersebut. Kemudian korban mendapatkan perhatian lebih dari orang tua dan teman-temannya, korban ditemani oleh orang sekitarnya agar tidak merasa kesepian atau diasingkan lalu korban juga mendapat tindakan konseling seperti sering diajak bertukar pikiran, mengeluarkan perasaan atau pikiran yang mengganggunya, mengajak bercerita dan mengeluarkan curahan hati yang terpendam di dalam benaknya.

Pengalaman komunikasi tidak menyenangkan yang didapat oleh korban seperti victim blaming yaitu sebagai korban ia justru disalahkan oleh orang-orang di sekitarnya yang tidak tahu cerita lengkapnya, mereka dianggap memancing pelaku pelecehan karena dikaitkan dengan pepatah tidak mungkin ada asap jika tidak ada api. Kemudian korban juga menerima olokan oleh teman-temannya yang tidak menganggap serius hal tersebut, sering kali pengalaman pelecehan tersebut dijadikan bahan bercanda sesama mereka. Lalu dimarahi oleh orang tua yang berpikiran negatif terhadap korban, mereka menganggap korban terlalu aktif didunia maya atau tidak mau mendengarkan orang tua sehingga menerima akibat dilecehkan oleh orang asing, dan juga korban sering kali dianggap mendramatisir apabila korban membagikan cerita seputar pengalaman pelecehan yang diterimanya, hal ini biasanya diungkapkan oleh orang-orang yang belum pernah mengalami cyber sexual harassment sehingga mereka menganggap remeh kejadiankejadian seperti ini. Berikut kategorisasi dari pengalaman komunikasi remaja korban cyber sexual harassment (pada gambar 1).

\section{SIMPULAN}

Dari hasil penelitian yang penulis lakukan dan penulis paparkan sebelumnya bahwa dimensi konsep diri remaja korban cyber sexual harassment di Kota pekanbaru yaitu dimensi internal yang terdiri dari diri identitas remaja korban cyber sexual harassment memandang diri mereka secara negatif. Perilaku mereka pesimis, tidak dapat mengontrol emosi dan sering menarik diri dalam berinteraksi, remaja mendapatkan penilaian yang negatif berupa label-label seksual dari temannya seperti "bahenol", "bohay", "cabe-cabean" dan sebagainya. Sehingga remaja merasa tidak senang dengan penilaian yang diberikan terhadap diri mereka, remaja menilai bahwa perilaku agresif, rendah diri dan tertutup diakibatkan karena remaja mengalami cyber sexual harassment tanpa mengetahui cara menghindarinya. Dimensi eksternal yang terdiri dari fisik dimana remaja merasa bentuk fisik atau wajah yang dimiliki dapat memancing pelecehan dan ada yang mensyukuri tanpa mengaitkan pelecehan tersebut, remaja merasa kurang baik dalam hal moral-etik karena jarang melakukan ibadah, dan tidak mengikuti ajaran yang disuruh agama, sedangkan diri personal remaja merasa diri personal buruk seperti menyukai kontroversi, pencemas, negatif thinking, sombong dan skeptis terhadap pujian, remaja merasa dihargai, diberi kasih sayang, dan merasa tidak dibeda-bedakan dengan anak lainnya meskipun mereka cenderung mengurangi interaksi dengan keluarga serta mereka merasa tidak nyaman ketika berada di keramaian dan menjauhi interaksi dengan lawan jenis, dan menutup pertemanan di dunia nyata dan dunia maya. Remaja korban cyber sexual harassment di Kota Pekanbaru memiliki konsep diri negatif.

Pengalaman komunikasi digambarkan sebagai bentuk pengalaman komunikasi antar pribadi antara orang tua, lingkungan 
pertemanan, sekolah dan lawan jenis. Pengalaman komunikasi tersebut berupa pengalaman komunikasi menyenangkan seperti motivasi, perhatian dan konseling, kemudian pengalaman komunikasi tidak menyenangkan seperti victim blaming, olokan, dimarahi orang tua, dan dianggap terlalu mendramatisir. Pengalaman komunikasi tidak menyenangkan lebih banyak berpengaruh pada persepsi diri sosial (penilaian seseorang terhadap dirinya dalam berinteraksi dengan lingkungan sekitar). Kondisi ini sebagian besar dialami oleh pelaku yang mendapatkan respons negatif dari orang tua dan teman-temannya saat mengalami cyber sexual harassment.

\section{DAFTAR PUSTAKA}

Abdullah, A. F. (2008). Studi fenomenologi pelecehan seksual pada wanita melalui sosial media. Sidoarjo: STKIP PGRI .

Agustiani, H. (2009). Psikologi perkembangan (pendekatan ekologi kaitannya dengan konsep diri dan penyesuaian diri pada remaja). Bandung : Rafika Aditama .

Arafa, A. E. (2018). Cyber sexual harassment : a cross-section survey over female university students in upper egypt. International Journal of Community Medicine and Public Health, Egypt, 5(1), 61-65 DOI: http://dx.doi.org/10.18203/2394-6040. ijcmph20175763.

Arifah, D. A. (2011). Kasus cybercrime di Indonesia. Jurnal Bisnis dan Ekonomi 18 (2), Hlm. 185 - 195 ISSN: 1412-3126.

Cangara, H. (2011). Komunikasi politik konsep, teori dan strategi. Jakarta : Grafindo.

Childnet. (2017). Young people's experiences of online sexual harassment. Dipetik Mei 30, 2021, dari https://www.childnet.com: https://www.childnet.com/ufiles/Project deSHAME_Dec_2017_Report.pdf

Creswell, J. W. (2016). Research design pendekatan kualitatif, kuantitatif, dan mixed. Yogyakarta : Pustaka Fajar .

Dreeva. (2019, Maret 25). SAFEnet (Southest Asia Freedom of Expression Network). Dipetik Juni 30, 2019, dari https://id.safenet. or.id: https://id.safenet.or.id/2019/03/ pelatihan-pencegahan-kbgo-di-pekanbaru/

Fajri, A. (2008). Cybercrime. Dipetik Mei 30, 2021, dari http://students.ee.itb.ac.id/fajri/ publication
Habibah, U. H., \& Tianingrum, N. A. (2020). Penggunaan media sosial terhadap pelecehan seksual pkada siswa sekolah di wilayah kerja puskesmas harapan baru Kota Samarinda. Borneo Student Research 1 (3), hlm. 1966-1971 eISSN: 2721-5727.

Handaningtias, U. R., \& Agustina, H. (2017). Peristiwa komunikasi dalam pembentukan konsep diri otaku anime. Jurnal Kajian Komunikasi, Volume 5, No. 2, hlm. 202-209 https://doi.org/10.24198/jkk.v5i2.11405.

Indainanto, Y. I. (2020). Normalisasi kekerasan seksual wanita di media online. Jurnal Komunikasi 14(2), hlm. 105-118. doi : https://doi.org/10.21107/ilkom.v14i2.6806.

Intan, H. W. (2015). Konsep diri remaja korban pemerkosaan. . Jakarta: Universitas Gunadarma.

Jasmine, T. (2021). Kumparan. Dipetik Maret 23, 2021, dari https://Kumparan.com: https://kumparan.com/tajna-jasmine/ pelecehan-seksual-terhadap-perempuandi-media-sosial-1uyDSs0ykK6

Juditha, C. (2020). Perilaku cybersex pada generasi milenial. Jurnal Pekommas, 5 (1), 47-58 DOI:10.30818/jpkm.2020.2050106.

Lisanawati, G. (2014). Pendidikan tentang pencegahan kekerasan terhadap perempuan dalam dimensi kejahatan siber. Jurnal Pandecta 9 (1), hlm. 1-15 DOI http:// dx.doi.org/10.15294/pandecta.v9i1.2852.

Moleong, L. (2010). Metodologi penelitian kualitatif. Bandung: Remaja Rosda karya .

Nashrullah, N. (2019). REPUBLIKA.co.id. Dipetik Juni 30, 2019, dari https://nasional. republika.co.id: https://nasional.republika. co.id/berita/nasional/daerah/pog61o320/ pencabulan-dominasi-kasus-kekerasaananak-di-pekanbaru

Noviana, I. (2015). Kekerasan seksual terhadap anak: dampak dan penanganannya child sexual abuse: impact and hendling. Sosio Informa 1 (1), 13-27 DOI: https://doi. org/10.33007/inf.v1i1.87.

Rahayu, M., \& Agustin, H. (2018). Representasi kekerasan seksual terhadap perempuan di situs berita Tirto.Id. Kajian Jurnalisme 2 (1), 115-134 ISSN 2549-1946.

Rakhmat, J. (2009). Psikologi komunikasi. Bandung: Remaja Rosda Karya.

Rahmah, D. D., Iriyanti, S., Maghfiroh, L., \& Agustina, N. (2017). Bibliotherapy: self 
help book meningkatkan self concept pada korban sexual harassment. Psikostudia: Jurnal Psikologi 6 (2), hlm. 50-57 ISSN: 2302-2582.

Reed, E., Wong, A., \& Raj, A. (2019). Cyber sexual harrassment: a summary of current measures and implications for future research. Journal $O f$ Violence Against Women, 1-14 DOI : 10.1177/1077801219880959.

Rosyidah, F. N., \& Nurdin, M. F. (2018). Perilaku menyimpang: media sosial sebagai ruang baru dalam tindak pelecehan seksual remaja. SOSIOGLOBAL: Jurnal Pemikiran dan Penelitian Sosiologi 2 (2), 38-48 DOI:10.24198/jsg.v2i2.17200.
Rusyidi, B., Bintari, A., \& wibowo, H. (2019). Pengalaman dan pengetahuan tentang pelecehan seksual:studi awal di kalangan mahasiswa perguruan tinggi. Share: Social Work Jurnal 9 (1), hlm. 75-85 Doi: 10.24198/share.v9i1.21685.

Santrock, J. (2007). Perkembangan anak jilid 1 edisi kesebelas. Jakarta: Erlangga .

Sugiyono. (2016). Metodologi penelitian kuantitatif, kualitatif, dan r\&d. . Bandung: Alfabeta .

Wirman, W. (2012). Pengalaman komunikasi dan konsep diri perempuan gemuk. Indonesian. Dipetik Mei 2021, 30 , dari http://jurnal.unpad.ac.id: http://jurnal. unpad.ac.id/ijad/article/view/2659 